\title{
Peningkatan Keterampilan Passing Bawah Bola Voli Melalui Metode Pembelajaran Kooperatif
}

\author{
Dicky Syatria $^{1}$, Yusmawati², Ramdan Pelana ${ }^{3}$ \\ 1,2,3 Universitas Negeri Jakarta \\ email: dickysyatria89@gmail.com
}

\begin{abstract}
This aims of this sstudy are to improve skills through under volleyball through cooperative learning methods. The method used in this study is action research. An interesting research flow on research put forward by Kemis and McTaggart. The results of this study indicate that as many as 17 of the 20 students were able to pass below well, or around $85 \%$, while students who did not complete about 3 students or around $15 \%$. From this study it can be concluded that through cooperative learning methods can significantly improve the skill of passing volleyball under.
\end{abstract}

Keywords: Passing, Volleyball, Learning, Cooperative

\begin{abstract}
Abstrak. Penelitian ini bertujuan untuk meningkatkan keterampilan passing bawah bola voli melalui metode pembelajaran kooperatif. Metode yang digunakan dalam penelitian ini yaitu penelitian tindakan (action research) Alur penelitian mengacu pada penelitian tindakan yang dikemukakan oleh Kemis dan Mc.Taggart. Hasil penelitian ini menunjukan sebanyak 17 dari 20 orang siswa mampu melakukan passing bawah dengan baik, atau sekitar 85\%, sedangkan siswa yang tidak tuntas sekitar 3 orang siswa atau sekitar 15\%. Dari penelitian tersebut dapat disimpulkan bahwa melalui metode pembelajaran kooperatif dapat meningkatkan keterampilan passing bawah bola voli secara signifikan.
\end{abstract}

Kata Kunci: Passing, Bola Voli, Pembelajaran, Kooperatif

\section{PENDAHULUAN}

Sekolah merupakan lembaga pendidikan yang mempunyai tugas untuk menghantarkan peserta didik mengembangkan segala potensi yang dimilikinya. Sekolah juga dipercaya sebagai salah satu pembentuk karakter individu siswa. Keberhasilan pendidikan di sekolah sangat bergantung pada proses pembelajaran di kelas. Kualitas proses pembelajaran sangat dipengaruhi oleh komponen-komponen di dalamnya yang saling berhubungan dan berkaitan satu sama lain. Komponen-komponen proses pembelajaran tersebut meliputi siswa, guru, tujuan pembelajaran, bahan pelajaran, metode pembelajaran, media dan evaluasi. 
Pendidikan Jasmani merupakan salah satu mata pelajaran yang wajib dilaksanakan di lingkungan persekolahan formal seperti di SD, SMP, dan SMA atau sederajat. Wajibnya pendidikan jasmani diajarkan di lingkungan sekolah formal dikarenakan mata pelajaran pendidikan jasmani secara eksplisit tercantum dalam Kurikulum disetiap jenjang pendidikan. Pendidikan jasmani merupakan proses pendidikan melalui aktivitas jasmani dan sekaligus merupakan proses pendidikan untuk meningkatkan kemampuan jasmani. Tujuan yang ingin dicapai melalui pendidikan jasmani pun mencakup pengembangan individu secara menyeluruh. Artinya, cakupan pendidikan jasmani tidak hanya berfokus pada aspek fisik saja, melainkan juga aspek mental, emosional, sosial dan spiritual. Tujuan ini berhubungan dengan kemampuan siswa dalam menyesuaikan diri pada suatu kelompok atau masyarakat.

Pendidikan jasmani terdapat beberapa cabang olahraga yang wajib diajarkan diantaranya permainan bola besar, permainan bola kecil, atletik, beladiri, kebugaran jasmani, senam dasar, senam tanpa alat, renang, perkemahan dan dasar-dasar penyelamatan, budaya hidup sehat serta penyakit menular seksual. Salah satu materi yang diajarkan kepada siswa di sekolah adalah permainan bola besar dengan subtopiknya yaitu permainan bola voli.

Permainan bola voli merupakan permainan beregu yang terdiri dari dua kelompok yang akan saling bertanding, dimana setiap kelompok terdiri dari 6 orang yang menempati lapangan petak masing-masing yang dibatasi oleh net, tiap kelompok harus berusaha memukul bola sampai melewati net dan akan mendapat poin 1 jika bola berhasil jatuh ke petak lawan (rally point), permainan selesai apabila salah satu tim mencapai angka 25. Dalam kedudukan 24-24, permainan dilanjutkan sampai tercapai selisih 2 (dua) angka. Menurut Ambar dan Susilo (dalam LPP Press UNJ, 2014 : 14) teknik dasar permainan bola voli terbagi menjadi empat yaitu bendungan (block),service,umpan (set-up) smash(spike) dan Passing. Dari kelima teknik tersebut, gerak dasar passing merupakan teknik yang sangat dominan dalam permainan bola voli karena bertujuan untuk mengumpan bola kepada teman satu tim agar memenangi suatu permainan/pertandingan.Passing bawah merupakan teknik memainkan bola dengan sisi lengan bawah bagian dalam baik dengan menggunakan satu atau pun dua lengan secara bersamaan. Kegunaan dari passing bawah bola voli antara lain adalah untuk menerima bola servis, menerima bola smash atau serangan dari lawan, untuk mengambil bola setelah terjadi block atau bola pantul dari net, untuk menyelamatkan bola yang terpantul keluar menjauhi lapangan permainan dan untuk mengambil bola rendah yang datang secara tiba-tiba.

Permainan bola voli pada sekarang ini tidak hanya merupakan olahraga yang bersifat rekreasi, sekedar alat untuk meningkatkan kesegaran jasmani saja, tetapi telah menuntut kualitas prestasi yang setinggi-tingginya. Dengan adanya tuntutan prestasi yang setinggi-tingginya, maka 
permainan bola voli sangat perlu diadakan pembinannya prestasi secara serius sejak dini serta kesinambungan, salah satunya melalui jalur pendidikan, Yaitu dengan mengadakan kegiatan ekstrakurikuler di sekolah. Ekstrakurikuler merupakan kegiatan yang dilaksanakan di luar jam pelajaran guna memperluas wawasan serta peningkatan dan penerapan nilai - nilai pengetahuan dan kemampuan dalam berbagai hal. Selain itu, kegiatan ekstrakurikuler juga merupakan salah satu cara menampung dan mengembangkan potensi siswa yang tersalurkan saat kegiatan pembelajaran pendidikan jasmani di sekolah.

Kegiatan ekstrakurikuler merupakan kegiatan yang dilaksanakan diluar jam pelajaran dan merupakan salah satu upaya pembinaan yang diselenggarakan dilingkungan sekolah guna peningkatan dan penerapan nilai-nilai pengetahuan dan kemampuan siswa dengan bentuk-bentuk latihan khusus sesuai cabang olahraga yang diikuti dan diminati. Hal ini sangat penting agar pembibitan dan pembinaan olahraga dikalangan siswa akan terus meningkat dan mencapai hasil yang maksimal. SMP Negeri 2 Solear Tangerang merupakan salah satu sekolah yang melaksanakan ekstrakurikuler bola voli, dan merupakan salah satu kegiatan ekstrakurikuler yang diminati siswa. Kegiatan ekstrakurikuler bola voli SMP Negeri 2 Solear Tangerang merupakan tempat pembinaan siswa pada cabang olahraga bola voli. Siswa yang memiliki minat dan bakat pada cabang bola voli dikembangkan agar memiliki keterampilan yang lebih baik pada cabang bola voli. Terutama dalam mengaplikasikan teknik dasar permainan bola voli, salah satunya Passing bawah.

Berdasarkan penjelasan diatas dapat disimpulkan bahwa passing bawah merupakan teknik dasar yang penting untuk dikuasai oleh siswa. Dari hasil pengalaman peneliti yang juga merupakan pelatih ekstrakurikuler bola voli di sekolah tersebut, kemampuan passing bawah siswa masih sangat kurang baik. Hal itu disebabkan karena kurangnya motivasi siswa dalam mengikuti latihan dan banyak siswa yang masih belum memahami dan kesulitan dalam melakukan gerak dasar passing bawah dalam permainan bola voli. Hal itu dapat dilihat dari cara mereka melakukan gerakan passing bawah bola voli masih terlihat jelas kesalahan-kesalahan dan masih banyak ditemukan siswa yang tidak mampu mempraktikkannya.

Metode yang digunakan dalam kegiatan pembelajaran juga mempunyai peranan yang cukup penting. Metode pembelajaran yang di gunakan untuk menunjang keterampilan anak dalam melakukan teknik passing bawah dalam permainan bola voli yaitu metode pembelajaran kooperatif. Secara garis besar kegiatan yang di lakukan secara berkelompok. Karena permainan bola voli di butuhkan kerja sama team. 


\section{METODE}

Metode yang digunakan dalam penelitian ini adalah penelitian tindakan (action research). Menurut Wina Sanjaya ( 2011 : 25) penelitian tindakan adalah penerapan berbagai fakta yang ditemukan untuk memecahkan suatu masalah dalam situasi sosial dan meningkatkan kualitas tindakan yang dilakukan dengan melibatkan kolaborasi dan kerjasama para peneliti dan praktisi. Sedangkan Menurut Kemmis (2014: 4) action research is "a practice-changing-practice".

Model penelitian tindakan yang dipakai dalam penelitian tindakan ini menggunakan model Kemmis dan Mc Taggart. Model ini dianggap sesuai dengan penelitian dengan mempertimbangkan penekanan pada menangani satu masalah saja. Penelitian ini terbatas yaitu: pada peningkatan gerak dasar passing bawah dalam permainan bola voli melalui pembelajaran kooperatif. Langkah-langkah penelitian ini terdiri dari tahap pertama meliputi perencanaan, tindakan, pengamatan dan refleksi. Desain intervensi tindakan yang dipilih yaitu pembelajaran koperatif untuk meningkatkan gerak dasar passing bawah dalam permainan bola voli. Tindakan yang dilakukan adalah membuat desain pembelajaran gerak dasar passing bawah dalam permainan bola voli yang dirancang berdasarkan rencana yang disusun.

Prosedur umum penelitian tindakan Kemmis dan Mc Taggart ini meliputi empat tahap yaitu: (1). Perencanaan (planning), (2). tindakan (acting), (3). pengamatan (observation), (4). refleksi (reflection). Model penelitian tindakan spiral ini bertujuan untuk memperbaiki praktik-praktik pembelajaran dan meningkatkan mutu proses belajar mengajar. Penelitian ini menggunakan siklus yang diciptakan oleh Kemmis dan Mc Taggart yakni seperti gambar berikut : bg helventa, wawan, elex, alex, ryan

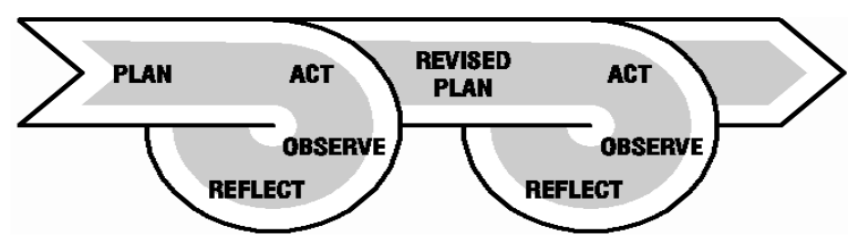

Gambar 1. Model spiral Kemmis dan Taggart

Sumber : Stephen Kemmis, et al, The Action Research Planner, (Springer, Singapore, 2014), h.19

Pada penelitian ini, peran peneliti adalah sebagai Instrumen kunci, meneliti dan terlibat langsung dalam keseluruhan proses penelitian, mulai dari kegiatan pra observasi, perencanaan, sampai pada tahap refleksi dalam setiap siklus. Selain itu, peneliti bertindak sebagai perencana, pengamat, pengolah, dan penganalisis data., maka untuk membuktikan keobjektivitas penelitian maka dokumen-dokumen seperti program latihan, hasil-hasil tindakan (treatment) serta tes perlu dilampirkan. Metode penelitian yang digunkaan adalah kualitatif dan kuantitatif yang bersifat 
parisipasif, kualitatif menjelaskan peristiwa yang dilakukan dalam penelitian ini sehingga mendapat gambaran dan penjelasan yang lengkap dalam pelaksanaan penelitian tindakan. Kuantitatif digunakan untuk menganalisa data hasil proses latihan siswa atau membandingkan hasil siswa sebelum dan sesudah penelitian tindakan dilakukan. Nilai ini akan diuji kebenarannya melalui metode tersebut untuk melihat seberapa besar signifikannya nilai sebelum dan sesudah dilakukan.

Merujuk pada langkah-langkah penelitian tindakan ini, maka langkah-langkah yang dilakukan dalam penelitian ini meliputi: (1) Perencanaan. (3) Pelaksanaan Tindakan. (3) Obsevasi. (4) Refleksi. Penelitian ini menggunakan dua siklus yang masing-masing siklus terdiri dari 8 kali latihan. Adapun langkah-langkah pertama adalah sebagai berikut :

\section{Perencanaan (planning)}

Perencanaan adalah suatu tahap atau proses kegiatan awal untuk perumusan masalah secara sistematis dan terprogram untuk mencapai tujuan agar mendapatkan hasil. Pada tahap perencanaan penelitian ini ada beberapa kegiatan yang dilakukan peneliti adalah sebagai berikut:

a) Membuat desain permainan, untuk dijadikan pedoman pembuatan gerak dasar Passing bawah dalam permainan bola voli melaui pembelajaran kooperatif.

b) Menyusun instrumen tes passing bawah dalam permainan bola voli.

c) Mendiskusikan rancangan gerakan dengan pembimbing Tesis.

d) Mempersiapkan peralatan yang akan digunakan dalam latihan

\section{Pelaksanaan Tindakan (action)}

Pelaksanaan tindakan menyangkut apa yang dilakukan peneliti sebagai upaya perbaikan, peningkatan atau perubahan yang dilaksanakan berpedoman pada rencana tindakan.

Dalam pelaksanaan penelitian ini, peneliti membuat dan melaksanakan:

a) Latihan gerak dasar passing bawah dalam permainan bola voli, melalui pembelajaran kooperatif yang sudah dirancang dan. Selanjutnya untuk dilaksanakan.

b) Pada penerapan rancangan melalui pembelajaran kooperatif ini peneliti menjadi pengamat, mencatat kegiatan penelitian (observer) yang terjadi di lapangan, sedangkan salah satu guru penjas di sekolah sebagai pelaksana tindakan/pelatih.

\section{Observasi}

Observasi merupakan kegiatan peneliti untuk melihat permasalahan latihan, khususnya dalam latihan gerak dasar passing bawah dalam permainan bola voli yang dilaksanakan di SMP Negeri 2 Solear Tangerang. Maksud observasi adalah untuk mengamati kegiatan pembelajaran dan menganalisis masalah-masalah yang terkait dengan fokus penelitian. 
Fokus masalah yang diteliti atau yang diobservasi meliputi kegiatan pembelajaran yang dilakukan oleh guru, model/metode/strategi/pendekatan yang digunakan oleh guru, respon siswa terhadap kegiatan pembelajaran, interaksi-interaksi akademik yang terjadi sebagai akibat tindakan yang diberikan oleh guru dan sarana prasarana pendukung pembelajaran yang terdapat di sekolah yang dijadikan tempat penelitian.

Data-data yang terkait dengan fokus penelitian yang diamati pada tahap observasi ini dicatat dalam catatan lapangan, yang selanjutnya dijadikan dasar-dasar pembuatan perencanaan tindakan dalam penelitian ini. Dalam penelitian ini, salah satu perencanaan yang dibuat peneliti adalah rancangan gerak dasar passing bawah dalam permainan bola voli. Sesuai dengan batasan masalah yang dikaji dalam penelitian ini, maka rancangan yang dibuat berorientasi pada pembelajaran kooperatif.

\section{Refleksi (reflection)}

Refleksi merupakan tahap yang dilaksanakan setelah tahap pelaksanaan. Pada tahap ini peneliti mengkaji, melihat, dan megevaluasi hasil-hasil atau respon dari tindakan yang telah dicatat dalam catatan lapangan. Tahap refleksi adalah bagian yang sangat penting dari penelitian tindakan. Refleksi yang ditekankan adalah evaluasi diri peneliti selaku pengamat dan hasil yang terjadi, yaitu berupa perubahan sebagai akibat diterapkannya pembelajaran kooperatif pada gerak dasar passing bawah dalam permainan bola voli, dengan tujuan untuk meningkatkan gerak dasar passing bawah permainan bola voli. Proses refleksi ini juga dikonsultasikan dengan pembimbingan.

Jika hasil refleksi terhadap tindakan satu sudah menyimpulkan bahwa permasalahan sudah terpecahkan, maka tahap penelitian tindakan dianggap cukup. Tetapi jika hasil refleksi pada siklus pertama masih mengandung masalah atau muncul masalah baru, maka penelitian tindakan kelas dilanjutkan dengan penelitian pada siklus ke II.

Kriteria keberhasilan tindakan penelitian ini dapat dilihat dengan meningkatnya gerak dasar passing bawah dalam permainan bola voli siswa yang dilihat secara kuantitatif. Pada setiap siklus akan dilakukan pengamatan dan pengukuran dengan analisis deskriptif untuk mengetahui bagaimana proses peningkatkan gerak dasar passing bawah dalam permainan bola voli sebelum dan sesudah adanya tindakan dan apakah kemampuan gerak dasar siswa sudah meningkat. Jika dari deskriptif persentase telah menunjukkan $75 \%$. Siswa diangap telah mengalami peningkatan gerak dasar passing bawah dalam permainan bola voli, maka keberhasilan penelitian sudah tercapai. 


\section{TEMUAN}

Setelah melakukan treatment pada siklus I diperoleh data yang ditunjukan pada table 1.

\section{Tabel 1. Distribusi Hasil Keterampilan Passing Bawah Bola Voli Siklus I}

\begin{tabular}{cccc}
\hline NO & RENTANG SKOR & FREKUENSI & PERSENTASE \\
\hline 1 & $58-62$ & 6 & $30 \%$ \\
\hline 2 & $63-67$ & 1 & $5 \%$ \\
\hline 3 & $68-72$ & 0 & $0 \%$ \\
\hline 4 & $73-77$ & 9 & $45 \%$ \\
\hline 5 & $78-82$ & 0 & $0 \%$ \\
\hline 6 & $83-87$ & 4 & $20 \%$ \\
\hline & JUMLAH & 20 & $100 \%$ \\
\hline
\end{tabular}

Berdasarkan data tersebut di atas dapat dikemukakan bahwa siswa yang tuntas sebanyak 13 orang $(65 \%)$ dan siswa yang belum tuntas sebayak orang $7(35 \%)$. Setelah melaksanakan kegiatan latihan dan menghitung data hasi penelitian, pelatih dan observer melakukan refleksi serta diskusi guna membahas permasalah yang berhubungan dengan tindakan yang telah dilakukan oleh pelatih. Terlihat pada siklus I masih terdapat kekurangan baik dari pelatih maupun dari siswa.

Dari data hasil pembelajaran pada siklus kesatu menunjukan bahwa kemampuan passing bawah bola voli belum mencapai target yang diharapkan, yakni target nilai 70. Meski demikian, selama proses pembelajaran pada siklus kesatu terdapat peningkatan motivasi dan keinginan siswa untuk belajar passing bawah bola voli. Pada tahap ini, siswa sudah mampu mempraktikan gerakan demi gerakan dalam teknik passing bawah bola voli. Meskipun demikian, peneliti masih berharap hasil tersebut dapat ditingkatkan lagi hingga mencapai target yang diharapkan.

Siklus II

Berdasarkan data hasil penelitian pada siklus II dapat dikemukakan bahwa siswa yang tuntas sebanyak 17 orang (85\%) dan siswa yang belum tuntas sebayak orang 3 (15\%). Untuk lebih jelasnya dapat dilihat pada table 2.

Tabel 2. Distribusi Hasil Keterampilan Passing Bawah Bola Voli Siklus I

\begin{tabular}{rccc}
\hline NO & RENTANG SKOR & FREKUENSI & PERSENTASE \\
\hline 1 & $67-71$ & 3 & $15 \%$ \\
2 & $72-76$ & 5 & $25 \%$ \\
3 & $77-81$ & 0 & $0 \%$ \\
4 & $82-86$ & 7 & $35 \%$ \\
5 & $87-93$ & 5 & $25 \%$ \\
& JUMLAH & 20 & $100 \%$ \\
\hline
\end{tabular}


Berdasarkan analisis statistik di atas dapat disimpulkan bahwa menunjukan peningkatan terhadap jumlah siswa yang berhasil tuntas dan sudah memenuhi Kriteria Ketuntasan $=70$, yaitu sebanyak 17 orang siswa yang tuntas atau sekitar 85\% dengan batas minimal nilai 70 dari 20 siswa. Sedangkan siswa yang tidak tuntas sekitar 3 orang siswa atau sekitar 15\%. Dari data tersebut hanya 2 siswa yang tidak tuntas, namun nilai mereka sudah hampir mencapai titik ketuntasan yaitu 70.

\section{DISKUSI}

1. Pra siklus

Dari hasil yang didapat pada data awal bahwa sebelum diberikan tindakan siswa belum menunjukan hasil belajar yang cukup baik atau belum memenuhi target latihan. Dari tes awal keterampilan passing bawah yang telah dilaksanakan oleh 20 siswa ektrakurikuler SMP Negeri 02 Solear Tangerang, diperoleh hasil bahwa sebanyak 20\% (4 orang) yang tuntas dengan diatas 70 , sedangkan $80 \%$ (16 orang) belum tuntas.

Hasil pengamatan peneliti selama proses observasi latihan yang dilaksanakan di SMP Negeri 02 Solear Tangerang, masih terdapat beberapa siswa yang mengalami kesulitan belajar, bentuk kesulitan itu terlihat dari bebragai aspek yakni, latihan masih didominasi oleh pelatih atau berpusat pada pelatih, karena tidak memberikan bentuk-bentuk permainan yang dapat mendukung terhadap program latihan, sehingga kurang terjadinya komunikasi antar siswa dengan pelatih maupun siswa dengan siswa. Hal tersebut dapat menimbulkan kejenuhan pada siswa, akibatnya sebagian besar siswa bersikap pasif dalam mengikuti latihan, sehingga menyebabkan hasil latihan siswa kurang.

siswa kurang antusias mengikuti latihan, siswa kurang memahami intruksi yang diberikan, siswa kesulitan melakukan gerakan passing bawah bola voli. Masih banyaknya kesalahan dalam setiap tahapan gerakan passing bawah bola voli, baik dari tahap awalan, pelaksanaan, akhiran sampai dengan tahap arah bola. Dengan begitu peneliti membuat perencanaan tindakan dengan metode bermain.

\section{Siklus I}

Berdasarkan Hasil tindakan pada siklus I diperoleh dari:

a. Data Siklus 1 Hasil keterampilan passing bawah siswa ektrakurikuler SMP Negeri 02 Solear Tangerang

Peningkatan keterampilan passing bawah dapat dilihat dari data yang diperoleh, Berdasarkan hasil tindakan pada siklus I menunjukkan peningkatan akan tetapi belum mencapai target latihan yaitu $80 \%$. Data siklus I menunjukan sebanyak 13 orang siswa yang tuntas atau 
sekitar 65\% dengan batas minimal nilai 70 dari 20 siswa. Sedangkan siswa yang tidak tuntas sebanyak 7 orang siswa atau sekitar $35 \%$.

Apabila dilihat dari data siklus satu terjadi peningkatan keterampilan akan tetapi belum memenuhi target 80\% ketuntasan yang diharapkan. Hal tersebut disebabkan karena sebagian siswa masi belum cukup memahami akan konsep gerak pada permainan yang diberikan, dan juga bentuk-bentuk permainannya masih belum terlalu banyak yang mengacu pada gerakan passing bawa.

b. Data Kualitatif hasil catatan lapangan pada siklus I

Hasil yang didapat oleh kolabolator selama mengamati berlangsungnya prosses tindakan pada siklus I terdapat beberapa anak yang masih mengobrol sendiri dan mengobrol dengan temanya serta kurang memperhatikan instruksi pelatih. Sehingga siswa masih belum memahami sepenuhnya tentang teknik dasar passing bawah. Sebagian siswa belum dapat melakukan gerakan teknik dasar gerakan teknik dasar passing bawah bola voli dengan benar. Siswa kurang bersungguh-sungguh dalam melakukan proses latihan. Berdasarkan data tersebut maka siklus I belum memenuhi target ketuntasan yang ditetapkan oleh peneliti.

\section{Siklus II}

Berdasarkan Hasil tindakan siklus II diperoleh dari :

a. Data Siklus II Hasil keterampilan passing bawah siswa ektrakurikuler SMP Negeri 02 Solear Tangerang

Berdasarkan analisis statistik di atas dapat disimpulkan bahwa menunjukan peningkatan terhadapap jumlah siswa yang berhasil tuntas dan sudah memenuhi target latihan $=70$, yaitu sebanyak 17 orang siswa yang tuntas atau sekitar 85\% dengan batas minimal nilai 70 dari 20 siswa. Sedangkan siswa yang tidak tuntas sekitar 3 orang siswa atau sekitar 15\%. Dari data tersebut hanya 2 siswa yang tidak tuntas, namun nilai mereka sudah hampir mencapai titik ketuntasan yaitu 75 .

Terjadi peningkatan keterampilan yang signifikan pada keterampilan passing bawah bola voli siswa ekstrakurikuler SMP Negeri 02 Solear Tangerang. Yang pada awalnya hanya 13 orang siswa yang tuntas setelah mengalami proses tindakan dalam 2 kali siklus maka jumlah siswa yang tuntas semakin banyak. Hasil tersebut menunjukan bahw target atau kriteria keberhasil yang sudah peneliti tetapkan sebelumnya sudah tercapai, yaitu 80\% dari jumlah keseluruhan siswa harus tuntas atau sudah memenuhi target latihan. Hal ini disebabkan karena konsep dan pola gerakan, serta peraturan permainan yang titetapkan sudah mengerti dan dipahami oleh peserta didik. Disamping itu, dengan menambahkan beberapa variasi gerakan peraminan yang baru yang 
lebih mengarah dan lebih menerapkan kepada pola gerakan passing bawah, membuat tujuan latihan mudah dicapai.

\section{b. Data Kualitatif hasil catatan lapangan pada siklus I}

Hasil yang didapat oleh kolaborator selama mengamati berlangsungnya proses latihan pada siklus II adalah sebagai berikut. Siswa sudah mulai dapat memahami sepenuhnya tentang teknik dasar passing bawah. siswa mulai dapat melakukan gerakan teknik dasar passing bawah bola voli dengan benar. Siswa mulai mengerti dan memahami tentang pola gerakan dan peraturan yang terdapat pada setiap permainan yang diberikan pelatih. Pelatih lebih sigap dan cepat tanggap dalam memberikan koreksi penjelasan gerakan yang sedang dilakukan.

Suatu penelitian tindakan dianggap berhasil apabila terjadi peningkatan keterampilan passing bawah bola voli pada siswa ekstrakurikuler SMP Negeri 02 Solear Tangerang. Keterampilan mencapai target latihan yang ditetapkan. Hal ini yang menjadikan indikator keberhasilan penelitian yang dilakukan. Hasil penelitian menunjukan bahwa melalui metode pembelajaran kooperatif dan latihan dengan intesitas tinggi dapat meningkatkan keterampilan passing bawah.

Pembelajaran dengan menggunakan metode pembelajaran kooperatif dengan menggunakan permainan yang dibuat dengan memperhatikan karakteristik siswa dapat meningkatkan hasil belajar passing bawah bola voli pada siswa ekstrakurikuler SMP Negeri 02 Solear tangerang tahun ajaran 2017/2018. Karakteristik siswa Sekolah Menengah sedang ada pada masa senang bermain. Dengan memanfaatkan berbagai permainan sebagai teknik latihan, kemampuan siswa ekstrakurikuler SMP Negeri 02 Solear Tangerang tahun ajaran 2017/2018 mempraktikan teknik passing bawah bola voli, meningkat. Siswa terlihat termotivasi mengikuti kegiatan latihan. Siswa terlihat senang dan nyaman. Pelatih lebih mudah melakukan pengelolaan latihan maupun pelaksanaan program latihan yang telah dibuat

Penerapan metode pembelajaran kooperatif dalam proses kegiatan latihan keterampilan passing bawah bola voli yang dikemas sedemikian rupa dapat menimbulkan hasil latihan yang lebih baik, karena siswa merasa antusias dan semangat dalam mengikuti latihan passing bawah bola voli pada siswa ekrakurikuler SMP Negeri 02 Solear Tangerang.

Berdasarkan pada data yang diperoleh pada pra siklus, siklus I dan siklus II terapat peningkatan di setiap siklusnya. Pada pra siklus terdapat 4 orang siswa yang mencapai nilai ketuntasan, dapat diartikan 4 orang siswa yang tuntas. Pada siklus ke I siswa yang tuntas sebanyak 13 orang atau sebesar 65\% dan pada siklus ke II naik menjadi 85\%. Hal ini menunjukan bahwa latihan dengan menggunakan metode kooperatif dan desain latihan yang menarik dapat meningkatkan keterampilan passing bawah pada siswa ektrakurikuler SMP Negeri 02 Solear 
Tangerang. Artinya, melalui metode pembelajaran kooperatif dapat meningkatkan ketereampilan passing bawah pada siswa ektrakurikuler SMP Negeri 02 Solear tahun ajaran 2017/2018.

\section{REFERENSI}

Ali Yusmar. (2017). "Upaya Peningkatan Teknik Permainan Bola Voli Melalui Modifikasi Permainan Siswa Kelas X SMA Negeri 2 Kampar". Jurnal Pendidikan dan Pengajaran Program Studi Pendidikan Guru Sekolah Dasar FKIP Universitas Riau, 1(1),246.

Alif Edo Yuniawan. et. al. (2012). "Modifikasi Model Pembelajaran Bola Voli Melalui Permainan Bola Voli Mini Berlapis". Journal of Physical Education, Sport, Health and Recreation (3). 188

Ambar Rina dan Susilo. (2014). Permainan Bola Voli Lanjutan. Jakarta:LPP Press UNJ.

Edwards William, H. (2010). Motor Learning and Control. USA: Wadworth..

Hasan. (2009). Action Research : Desain Penelitian Integratif untuk Mengatasi permasalahan Masyarakat. Akses : Jurnal dan Ekonomi. (04). 178-179.

Isjoni. (2013). Cooperative Learning Efektifitas Pembelajaran Kelompok. Bandung: Alfabeta. . (2011). Pembelajaran Kooperatif. Yogyakarta: Pustaka Pelajar.

Izzul Muttaqin. et. al. Pengembangan Model Latihan Smash Bolavoli pada Kegiatan Ekstrakurikuler di SMPN 12 Malang. Pendidikan Jasmani. Volume 26(02).6

Juliantine, T. et al.(2013). Model-Model Pembelajaran Dalam Pendidikan Jasmani. Bandung: Bintang WarliArtika.

Jumanta Hamdayama.(2014). Model dan Metode Pembelajaran Kreatif dan Berkarakter. Bogor: Ghalia Indonesia.

Kemmis, S. et al. (2014). The Action Research Planner. Singapore: Springer.

Kusumah, W. et al. (2013). Penelitian Tindakan Kelas. Jakarta: Indeks.

Rusman. (2012). Model-Model Pembelajaran. Jakarta: Raja Grafindo Persada.

Sanjaya, Wina. (2011). Penelitian Tindakan, Jakarta: Kencana.

Slavin E. Robert, (2010). Cooperative Learning: Teori Riset dan Praktik terjemahan Narulita Yusron. Bandung: Nusa Media.

Stephen Kemmis, et al. (2014). The Action Research Planner. Singapore : Springer. 
Sujadi, Eko Sujadi., Ayumi, Rinda Tri., Indra, Syaiful., Sumarto., MRA, Raja Rahima. (2018).Layanan Konseling Kelompok dengan Menggunakan Pendekatan Cognitive Behavioral untuk Membentuk Internal Locus of Control. Jurnal Fokus Konseling, 2 (2): 176184. https://doi.org/10.26638/jfk.626.2099

Sujadi, Eko., Meditamar, Muhd. Odha., Ahmad, Bukhari., Rahayu, Anita. (2018). Pengaruh Konsep Diri dan Locus of Control Terhadap Motivasi Berprestasi. Educational Guidance and Counseling Development Jounal, 1 (1): 32-51. dx.doi.org/10.24014/egcdj.v1i1.4808

Taniredja, T. et al. (2013). Penelitian Tindakan Kelas. Bandung: Alfabeta.

Tangkudung, J. (2016). Macam-macam Metodologi Penelitian Uraian dan Contohnya. Jakarta: Media Pustaka.

Tite Juliantine. (2013). Model-model pembelajaran dalam pendidikan jasmani. Bandung: Bintang Warliartika.

Widiastuti. (2015). Tes dan Pengukuran Olahraga. Jakarta: Raja Grafindo Persada. . (2014). Pembelajaran Gerak. Jakarta: PPs UNJ.

Yosef Nossek. (2010). Teori Umum Latihan.Jakarta : Institusi Nasional Olahraga. 